\title{
Genetic heterogeneity of proteolytic bacteria isolated from sediments mangrove areas based on repetitive sequence-based polymerase chain reaction and 16S-rRNA gene sequences
}

\author{
WILIS ARI SETYATI ${ }^{1, \bullet}$, ERNI MARTANI ${ }^{2}$, TRIYANTO ${ }^{2}$, MUHAMMAD ZAINUDDIN ${ }^{3}$, MAYA PUSPITA ${ }^{4}$, \\ CHRISNA ADI SURYONO ${ }^{1}$, SUBAGYO ${ }^{1}$, DELIANIS PRINGGENIES ${ }^{1, \bowtie \bullet}$ \\ ${ }^{1}$ Department of Marine Science, Faculty of Fisheries and Marine Science, Universitas Diponegoro. Jl. Prof. Soedarto SH, Tembalang, Semarang 50275, \\ Indonesia. Tel.: +62-24-7474698, Fax.: +62-24-7474698, "email: wilisarisetyati@yahoo.co.id, "pringgenies@yahoo.com \\ ${ }^{2}$ Faculty of Agriculture, Universitas Gadjah Mada. Jl. Flora, Bulaksumur, Sleman 55281, Yogyakarta, Indonesia \\ ${ }^{3}$ Department of Aquaculture, Universitas Islam Nadhlatul Ulama. Jl. Taman Siswa, Jepara 59427, Central Java, Indonesia \\ ${ }^{4}$ Universite Bretagne Sud. EA. LBCM, IUEM, F-56000 Vannes, France, 3884
}

Manuscript received: 27 July 2019. Revision accepted: 20 October 2019.

\begin{abstract}
Setyati WA, Martani E, Triyanto, Zainuddin M, Puspita M, Suryono CA, Subagyo, Pringgenies D. 2019. Genetic heterogeneity of proteolytic bacteria isolated from sediments mangrove areas based on repetitive sequence-based polymerase chain reaction and $16 S$ rRNA gene sequences. Biodiversitas 20: 3256-3261. Intensive shrimp farming has organic waste that results in pollution. Such waste needs to be bio-remediated for liquid waste. This study aimed to discover bacteria isolated from mangrove sediments that can degrade organic matter and apply them for bioremediation of polluted shrimp farms. The study consisted of bacterial isolation, bioassay of enzymatic activity, and isolates identification through cluster analysis. Bacterial isolates were collected from mangrove ecosystems in Rembang (R), Cilacap (C), Banyuwangi (B), and Karimunjawa (K). Enzymatic activity test consists of proteolytic, amylolytic, cellulolytic, lipolytic, and ligninolytic activity. Identification analysis was conducted with 16S-rRNA gene sequences followed by cluster analysis using the results of Rep-PCR. There were 19 isolates derived from proteolytic mangrove area represented in five clusters (groups). Group 1 consisted of 5 isolates; isolates 14.C, 22.R, 28.K, 15.C and 19.R. Group 2 consisted of 5 isolates; 30.K, 33.K, 34.K, 39.K and 40.B. Group 3 consisted of 3 isolates of bacteria; 13.C, 2.C and 32.C. Group 4 consisted of 5 isolates; isolates 36.K, 35.K, 37.K, 38.K and 48.B. Group 5 consisted of 1 isolate was isolate 26.R. The results of the sequences analysis of the 16S-rRNA gene indicated that the isolate 13C of the Group 3 had 97\% sequence homology with Bacillus oceanisediminis strain H2. Isolate 14.C of the Group 1 had 96\% sequence homology with Halomonas aquamarina strain DSM 30161. Isolate 26.R of the Group 5 had $98 \%$ sequence homology with Acinetobacter pitti strain ATCC 19004. Isolate 30.K of the Group 2 had 93\% sequence homology with Salinicola salarius strain M27. Isolate 36.K of the Group 4 had 97\% sequence homology with Bacillus aquimaris strain TF-12. Please write here your concluding remarks based on your results obtained.
\end{abstract}

Keywords: 16S-rRNA gene, heterogeneity, mangrove, proteolytic bacteria, rep PCR

\section{INTRODUCTION}

Cultivation of brackish fisheries produces large amounts of organic waste discharged into the surrounding environment. Most of this organic waste comes from feed residues (uneaten feed) and feces (Qian et al. 2001; Holmer et al. 2007). Suspended solids in aquaculture have the potential to pollute the ponds leading to a decrease in the carrying capacity of ponds for shrimp farming. Therefore, bioremediation efforts are critical to conducting as a solution to reduce organic wastes in shrimp farming ponds. The high content of total nitrogen correlates with the protein content; thus, it suggests that to reduce the content of sediment organic matter primarily involves the role of proteolytic bacteria.

The mangrove ecosystem is the most productive in the coastal area, which is seven times higher than other coastal ecosystems. The productivity of mangroves is represented through their litterfall and decomposition of mangrove leaves. Diversity of the organic components from mangrove litters might become a nutritious source for different types of microorganisms having capabilities to produce extracellular enzymes to decompose the litters. The idea of using microorganism-producing extracellular enzymes from a mangrove ecosystem serving as a bioremediation agent of organic matter and biocontrol in shrimp farming might be interesting to develop in the future. These microorganisms might be used as a source of the bacterial isolate to be formed as a consortium of probiotics to decompose the organic wastes.

Mangrove is a coastal wetland forest mainly found in estuary intertidal, backwater, delta, creeks, lagoon, marsh, and mudflat zones in the tropical and sub-tropical zone (Sahoo and Dhal 2009). Mangrove forests are known as a productive ecosystem (Hoq et al. 2002; Kristensen et al. 2008), resulting in 4.26-3.58 $\mathrm{g} \mathrm{m}^{-2}$ day $^{-1}$ of litterfall (Bernini and Rezende 2010). As a consequence, mangrove sediments are habitats that are biologically rich and provide unique ecological agents for a wide range of organisms, including microorganisms (Sahoo and Dhal 2008). Results of research on microorganisms in mangrove ecosystems show that in tropical mangroves bacteria and fungi occupy 
$91 \%$ of total biomass, whereas algae and protozoa occupy only $7 \%$ and $2 \%$ of total biomass (Holguin et al. 2001). Total heterotrophic bacteria (THB) in decomposed mangrove leaves Rhizophora mucronata (8-40 days) ranges from $0.24 \times 10$ to $0.95 \times 10 \mathrm{CFU} \mathrm{g}^{-1}$, whereas in Avicennia marina ranges from $0.28 \times 10$ to $0.99 \times 10 \mathrm{CFU} \mathrm{g}^{-1}$ (Kathiresan et al. 2011). Based on the depth of the sediment, it is found that the population of microorganisms classified into three sections. At the topsoil section, there is $2.437 \pm 0.821 \times 10 \mathrm{CFU} \mathrm{g}^{-1}$ dry weight, $10.966 \pm 0.725 \times$ $10 \mathrm{CFU} \mathrm{g}{ }^{-1}$ dry weight in the middle and $9.647 \pm 0.788 \times$ $10 \mathrm{CFU} \mathrm{g}^{-1}$ dry weight at the bottom (Das et al. 2011). Results of the bacterial community profile study based on the culture-independent PCR-denaturing gradient gel electrophoresis (DGGE) classify the bacteria into Proteobacteria, Bacteroidetes, Gemmatimonadetes, Actinobacteria, and Firmicutes groups.

According to Holguin et al. (2001) and Sahoo and Dhal (2008), microorganism activity plays a significant role in the process of nutrient transformation within the mangrove ecosystem. This transformation process involves the work of extracellular enzymes. Mahasneh (2001) research on the bacterial composition of the maize leaf composition of Avicennia marina showed that the proteolytic, amylolytic, cellulolytic and lipolytic bacteria were $21.86 \%, 30.32 \%$, $20.70 \%$, and $3.45 \%$, respectively. According to Gupta et al. (2007), most bacteria (from 567 total bacterial isolates) were amylase and protease enzyme producers, and only 41 lipase-producing bacteria, 33 phosphate-dissolving bacteria. The result of bacterial identification and ability to produce extracellular enzyme by Bacillus sp generates amylase, lipase, chitinase, and protease, but is unable to produce cellulase. Lactobacillus (L. brevis, L. fermentum, L. lactis, and L. buchneri), Actinobacteria sp, and Azotobacter sp produce amylase, lipase, chitinase, protease and cellulase.

Previous researches on microorganisms in the mangrove ecosystem showed the existence of antimicrobial activity. Gupta et al. (2007) in their study obtained 26 isolates from a total of 567 bacterial isolates showing antifungal activity with a broad spectrum of inhibition. Annamalai et al. (2009) obtained Enterococcus faecium isolates that was capable of producing enterocin showing a broad spectrum of inhibition against gram-positive and gram-negative bacteria such as Lactobacillus plantarum, Enterococcus facealis, Listeria monocytogens and Salmonella paratyphii, obtained four isolates of tolerant bacteria and capable of degrading phenols which also showed antibacterial activity against some pathogens (Salmonella typhi, Streptococcus pyogenes and Klebsiella pneumonia). These four isolates were identified as Pseudomonas aeruginosa, Micrococcus luteus, Shigella dysenteriae, and Bacillus cereus. In this study, heterogeneity studies of proteolytic bacteria originating from mangrove areas based on repetitive DNA sequences and 16S-rRNA gene sequences was conducted.

\section{MATERIALS AND METHODS}

\section{Sediment sampling and bacterial isolation}

Mangrove has collected sediments from several locations, i.e. the district of Rembang (R), Cilacap (C), Banyuwangi (B), and Karimunjawa (K). Sediment samples were taken at a depth of $10 \mathrm{~cm}$. Sediment samples were inserted into the sample container in a cold box, then diluted up to $10^{5}$ fold. Each level of dilution was spread on Zobel media and incubated at $37^{\circ} \mathrm{C}$ for one day. Colonies with different morphology were transferred to a new media three times to obtain a pure culture.

\section{Isolation and purification of DNA}

Pure bacterial isolates were cultured in Zobell 2216E liquid medium at $37^{\circ} \mathrm{C}$ for 24 hours. Bacterial cells from $1.5 \mathrm{~mL}$ culture were recovered by centrifugation at 10.000 rpm for $5 \mathrm{~min}$ and discarded the supernatant. Pellets were suspended with $250 \mu \mathrm{L} \mathrm{TE}$, and $100 \mu \mathrm{L}\left(20 \mathrm{mg} \mathrm{mL}^{-1}\right)$ lysozyme were added. The suspensions were incubated at $37^{\circ} \mathrm{C}$ for $1 \mathrm{~h}$ and $100 \mu \mathrm{L}$ SDS $10 \%$ was added to form as mucus. Later, they were added with $10 \mu \mathrm{L}$ of the enzyme proteinase $\mathrm{K}(10 \mathrm{mg} / \mathrm{L})$ and were incubated for $1 \mathrm{~h}$ at 37 ${ }^{\circ} \mathrm{C}$. Further, pellets were coupled with $100 \mu \mathrm{L} 5 \mathrm{M} \mathrm{NaCl}$, were homogenized, were added with $1001 \mathrm{CTAB}$, and were incubated at $65{ }^{\circ} \mathrm{C}$. for $20 \mathrm{~min}$. A $500 \mu \mathrm{L}$ of phenol: chloroform: isoamyl alcohol solution (25: 24: 1) were put in the pellets and were centrifuged at $13.000 \mathrm{rpm}$ for 15 min. The liquid phase was taken and was put into a new microtube, then was added with $500 \mu \mathrm{L}$ of chloroform and isoamyl alcohol (24: 1) and were shaken, and centrifuged at $13.000 \mathrm{rpm}$ for $5 \mathrm{~min}$. The liquid phase was taken, and the volume was measured. It was then added with cold isopropanol as much as the volume obtained in the liquid phase and homogenized, and incubated at-20 ${ }^{\circ} \mathrm{C}$ for 20 minutes. In the next steps, the microtube was centrifuged at $13.000 \mathrm{rpm}$ for $5 \mathrm{~min}$, the supernatant was discarded and $70 \%$ cold ethanol was added into the pellets. The tube was centrifuged at $13.000 \mathrm{rpm}$ for $5 \mathrm{~min}$, and the supernatant was carefully removed, followed by drying overnight. In the end, $30 \mu \mathrm{L}$ dd $\mathrm{H}_{2} \mathrm{O}$ was added. The DNA obtained was used for the analysis of 16S-rRNA via Polymerase Chain Reaction (PCR) (Marchesi et al. 1998).

\section{Antibacterial and enzymatic activity}

Amplification of repetitive sequences was performed by mixing DNA (50 ng) with PCR PuReTaqReady-To-Go PCR Beads kit (containing deoxynucleoside triphosphate at $200 \mu \mathrm{M}, 2.5$ UpuReTaq-DNA polymerase, $10 \mathrm{mM}$ Tris$\mathrm{HCl}(\mathrm{pH} 9.0), 50 \mathrm{mM} \mathrm{KCl}, 1.5 \mathrm{mM} \mathrm{MgCl}_{2}$ and sterile deionized water to $25 \mu \mathrm{L}$ ) and BOX A1R primers (59CTACGGCAAGGCGACGCTGACG-39) (Mohammed et al. 2009). PCR amplification was performed by thermal cycle: initial denaturation $\left(95^{\circ} \mathrm{C}, 7 \mathrm{~min}\right)$, followed by 30 cycles consisting of denaturation $\left(94^{\circ} \mathrm{C}, 1 \mathrm{~min}\right)$, annealing $\left(53{ }^{\circ} \mathrm{C}, 1 \mathrm{~min}\right)$ and extension $\left(65^{\circ} \mathrm{C}, 8 \mathrm{~min}\right)$, and final extension $\left(65^{\circ} \mathrm{C}, 16 \mathrm{~min}\right)$. The amplification products were then detected by electrophoresis on a $1.5 \%(\mathrm{w} / \mathrm{v})$ agarose gel in $0.5 \times$ Tris acetate-EDTA (TAE) buffer. Staining process was conducted using ethidium bromide 
and visualized under UV light. Rep-PCR fingerprints were further clustered using the Unweighed Paired Group Arithmetic Average (UPGMA) method (Tran et al. 2011; Wullschleger et al. 2013). Subsequently, dendrograms were created using the program of HYPERLINK (Wullschleger et al. 2013).

\section{Amplification of 16S-rRNA}

Amplification of the 16S-rRNA gene was performed using RTG PCR Beads kit and universal primary specific prokaryotes (Marchesi et al. 1998), 63f (5'CAGGCCTAACACATGCAAGTC) and 1387r (5 'GGGCGGWGTGTACAAGGC). The thermal cycles used for the amplification process were of: Pre-PCR $\left(94{ }^{\circ} \mathrm{C}, 2\right.$ min), denaturation $\left(92^{\circ} \mathrm{C}, 30\right.$ cycles), primer annealing (55 ${ }^{\circ} \mathrm{C}, 30$ cycles), elongation $\left(75^{\circ} \mathrm{C}, 1 \mathrm{~min}\right)$, and post extension at $75^{\circ} \mathrm{C}$ for $5 \mathrm{~min}$, with a cycle of 30 times.

\section{Sequencing}

Sequencing was carried out using the Big Dyne terminator V3.1 dye and an automated DNA sequencer ABI 3130 XL Genetic Analyzer Applied Biosystem. Sequencing is done with the aim of seeing the composition of acid-base forming DNA sequences.

\section{Blast analysis}

Analysis of DNA sequences of the best bacterial isolates is then compared with DNA sequences in DNA databases. Database searches are carried out using the internet through the Basic Local Alignment Search Tool (BLAST) database tracking program at the National Center for Biotechnology Information, National Institute for Health, USA (www.ncbi.nlm.nih.gov) (Emerson et al. 2008; Mohan et al. 2016).

\section{Data analysis}

The research data obtained were analyzed using descriptive methods. Homology of DNA sequence sequences was determined using BLAST (Altschul et al. 1997 in Kwon et al. 2002). Furthermore, phylogenetic tree construction is carried out using the Clustal $\mathrm{X}$ program (version 1.60).

\section{RESULTS AND DISCUSSION}

PCR BOX analysis on 19 isolates of proteolytic bacteria from the selected mangrove ecosystem showed that there was a variation of band pattern as illustrated in Figure 1. This variation indicated the presence of different types of bacteria.

Based on the electrophoresis gel visualization of RepPCR amplification product, the marker used in this study showed 10 bands (band 1-10). Visually, there were variations of band patterns in each sample. Comparison between the marker's and sample's band showed that there was a similarity between them as seen in isolate $2 \mathrm{C}, 13 \mathrm{C}$, 14C, 15C, 19R, 22R, 26R, 28K, 30K, 32K, 33K, 34K, 35K, $36 \mathrm{~K}, 38 \mathrm{~K}, 39 \mathrm{~K}, 40 \mathrm{~B}$, and $48 \mathrm{~b}$. In $2 \mathrm{C}$ isolate, there were four same bands (no. 1, 2, 6 and 7), five bands from 13C (no. 1, 2, 3, 6 and 7), four bands from 14C (no. 1, 3, 4, and 9), three bands from 15C (no. 1, 8 and 9). Isolate no. 19R had three same bands as the marker (no. 1, 8 and 9), three same bands from 22R (no. 1, 9 and 10), two bands from 26R (no. 1 and 6) and 28K (no. 1 and 9). As for the isolate no $30 \mathrm{~K}$ and $32 \mathrm{~K}$, there were three (no. 1, 7 and 10) and five same bands (no. 1, 3, 5, 6 and 7). Isolate no $33 \mathrm{~K}$ and $34 \mathrm{~K}$ had six bands that were the same as the marker, they are bands no. 1, 3, 5, 6, 9 and 10 and bands no. 1, 5, 6, 7, 9 and 10 , respectively. Isolates no. $35 \mathrm{~K}, 37 \mathrm{~K}$ and $40 \mathrm{~B}$ had four bands similar to those the marker, i.e., bands no. $1,4,7$ and 9; no. 1, 4, 6 and 7; and 1, 5, 7 and $10.36 \mathrm{~K}, 37 \mathrm{~K}, 38 \mathrm{~K}$ and 39K showed five (no. 1, 2, 5, 7 and 9), four (no. 1, 4, 6 and 7), three (no. 1, 2 and 9), and seven (no. 1, 3, 5, 6, 7, 9 and 10) bands that were the same as the marker. Then, isolates no 48B had five same bands, namely band no. 1, 2, 4, 7 and 9.

Dendrogram (Figure 2) shows that there are five groups based on similarity value, and it was equipped with bootstrapping value (repetition count 1000). Group 1 consisted of five bacterial isolates, namely isolates $14 \mathrm{C}$, 22R, 28K, 15C and 19R with bootstrapping values 10-77. Among the five isolates, bacterial isolate $14 \mathrm{C}$ had the best proteolytic activity with $14.915 \pm 0,474 \mathrm{~mm}^{2}$, amylolytic activity with $14.130 \pm 0.614 \mathrm{~mm}^{2}$, cellulolytic activity with $3.925 \pm 0.062 \mathrm{~mm}^{2}$, lipolytic activity with $5.495 \pm 0.473$ $\mathrm{mm}^{2}$, ligninolytic activity $14.915 \pm 0.611 \mathrm{~mm}^{2}$. This bacterial isolate showed a generation number $5.367 \pm$ 0.021 , generation time $6.708 \pm 0.026 \mathrm{~h}$, and growth rate $0,103 \mathrm{~h}^{-1}$. Group 1 had a similarity value of $40-50 \%$, which was the similarity between $14 \mathrm{C}$ and $22 \mathrm{R}, 15 \mathrm{C}$, and $19 \mathrm{R}$ with $40 \%$, and $50 \%$ between $14 \mathrm{C}$ and $28 \mathrm{~K}$.

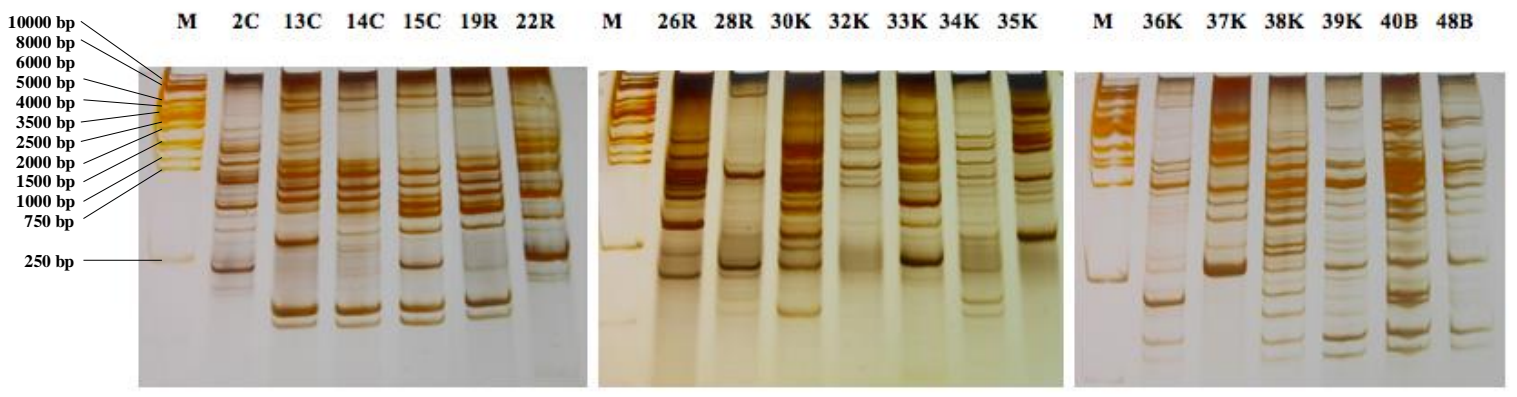

Figure 1. Visualization of Electrophoresis Results of RP-PCR Amplification Products by using BOX AIR 


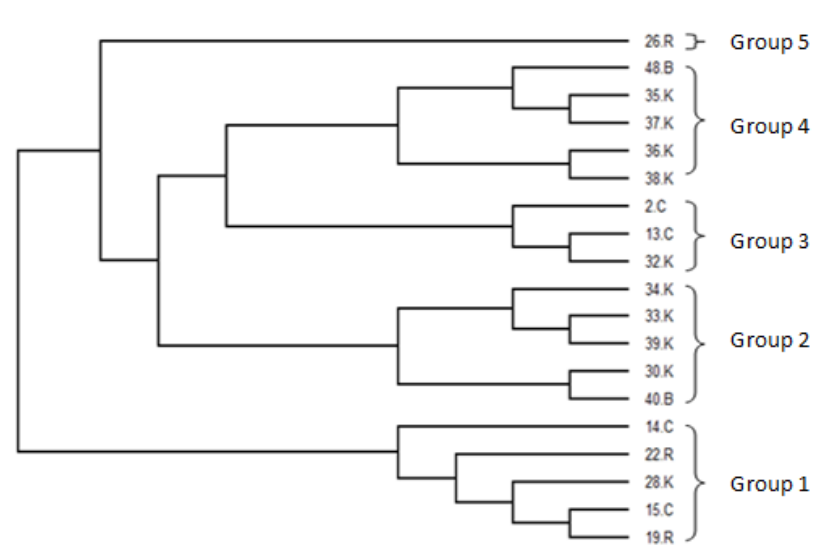

Figure 2. Dendrogram grouping of mangrove sedimentary bacterial isolates based on the amplification Rep-PCR products

Group 2 consisted of five bacterial isolates, namely isolates no. $30 \mathrm{~K}, 33 \mathrm{~K}, 34 \mathrm{~K}, 39 \mathrm{~K}$, and $40 \mathrm{~B}$ with bootstrapping values 3-55. Among these five isolates, bacterial isolate no. $30 \mathrm{~K}$ had the best activities. Proteolytic, amylolytic, cellulolytic, lipolytic, and ligninolytic activity of bacterial isolate $30 \mathrm{~K}$ were $13.345 \pm 0.412 \mathrm{~mm}^{2}, 13.345$ $\pm 0.425 \mathrm{~mm}^{2}, 14.130 \pm 0.441 \mathrm{~mm}^{2}, 5.495 \pm 0.532 \mathrm{~mm}^{2}$, and $6.280 \pm 0.584 \mathrm{~mm}^{2}$, respectively. Antibacterial activity of bacterial isolate $30 \mathrm{~K}$ against Vibrio harveyi, $V$. alginolitycus, and $V$. parahemolitycus were $4.710 \pm 0.059$ $\mathrm{mm}^{2}, 0.785 \pm 0.053 \mathrm{~mm}^{2}, 0.785 \pm 0.052 \mathrm{~mm}^{2}$. Generation number of this isolate was $5.491 \pm 0.123$, generation time was $6.559 \pm 0.147 \mathrm{~h}$, and its growth rate was $0.106 \mathrm{~h}^{-1}$. The similarity value of group 2 ranged from 25 to $60 \%$, namely the similarity between $30 \mathrm{~K}$ and $33 \mathrm{~K}, 34 \mathrm{~K}, 39 \mathrm{~K}, 38 \mathrm{~K}$ and $40 \mathrm{~B}$ with $25 \%, 57 \%, 38 \%$, and $60 \%$, respectively.

Group 3 consisted of three bacterial isolates, i.e., isolates $13 \mathrm{C}, 2 \mathrm{C}$, and $32 \mathrm{C}$ with bootstrapping values 9-42

. Among the three isolates, bacterial isolate $13 \mathrm{C}$ had the best bioactivities. Proteolytic activity was $25.120 \pm 0.497$ $\mathrm{mm}^{2}$, amylolytic activity was $29.830 \pm 0.550 \mathrm{~mm}^{2}$, cellulolytic activity $18.840 \pm 0,540 \mathrm{~mm}^{2}$, lipolytic activity was $2,355 \pm 0,057 \mathrm{~mm}^{2}$, ligninolytic activity $10.990 \pm$ $0.509 \mathrm{~mm}^{2}$, antibacterial activity against $V$. harveyi was $2.355 \pm 0.062 \mathrm{~mm}^{2}$, with generation number, time, and growth rate were $5.256 \pm 0.008,7.991 \pm 0.012 \mathrm{~h}$, and 0,087 $\mathrm{h}^{-1}$, respectively. Group 3 had a similarity value of $67-71 \%$, i.e., the similarity between $13 \mathrm{C}$ and $2 \mathrm{C}$.

Group 4 consisted of five bacterial isolates, i.e., 36K, $35 \mathrm{~K}, 37 \mathrm{~K}, 38 \mathrm{~K}$, and $48 \mathrm{~B}$ with bootstrapping values $8-32$. $36 \mathrm{~K}$ showed the best bioactivities of proteolytic $(9.420 \pm$ $\left.0.558 \mathrm{~mm}^{2}\right)$, amylolytic $\left(7.850 \pm 0,518 \mathrm{~mm}^{2}\right)$, cellulolytic $\left(12.560 \pm 0.558 \mathrm{~mm}^{2}\right)$, lipolytic $\left(4.710 \pm 0.273 \mathrm{~mm}^{2}\right)$, antibacterial against $V$. harveyi $\left(7.065 \pm 0.532 \mathrm{~mm}^{2}\right), V$. alginolitycus $\left(2.355 \pm 0,044 \mathrm{~mm}^{2}\right)$, and $V$. parahemolitycus $\left(3.925 \pm 0.041 \mathrm{~mm}^{2}\right)$. The generation number was $5.207 \pm$ 0.029 , the generation time was $4.609 \pm 0.026 \mathrm{~h}$, and the growth rate was $0.150 \mathrm{~h}^{-1}$. Group 4 had a value of similarity of $38-67 \%$, i.e. similarity between $36 \mathrm{~K}$ and $35 . \mathrm{K}$ $(57 \%)$, 37K (38\%), 38K (67\%), and with 48B (57\%).
Group 5 consisted of one bacterial isolate (26R) with bootstrapping value 3 . Isolate $26 \mathrm{R}$ had proteolytic activity of $3.140 \pm 0.053 \mathrm{~mm}^{2}$, amylolytic activity of $6.280 \pm 0.064$ $\mathrm{mm}^{2}$, cellulolytic activity of $3.140 \pm 0.053 \mathrm{~mm}^{2}$, lipolytic activity of $25.120 \pm 1.958 \mathrm{~mm}^{2}$, ligninolytic activity of $9.420 \pm 0.124 \mathrm{~mm}^{2}$, antibacterial activity against $V$. harveyi of $3.925 \pm 0.082 \mathrm{~mm}^{2}$, and against $V$. parahemolitycus of $4.710 \pm 0.054 \mathrm{~mm}^{2}$. The generation number of $26 \mathrm{R}$ was $5.841 \pm 0.069$, the generation time was $6.164 \pm 0.073 \mathrm{~h}$, and the growth rate was $0.112 \mathrm{~h}^{-1}$. Isolate $26 \mathrm{R}$ has a similarity value to other isolates in groups of $1,2,3$, and 4 of $14-50 \%$.

Based on cluster analysis, there were five groups with five isolates representing each group. The isolates representing each group were selected based on enzymatic activity (proteolytic, amylolytic, cellulolytic, lipolytic and ligninolytic), antibacterial inflammation of vibriosis bacteria, and growth rates, they were $13 \mathrm{C}, 14 \mathrm{C}, 26 \mathrm{R}, 30 \mathrm{~K}$, and $36 \mathrm{~K}$.

The purification of the 16S-rRNA gene amplification products of $13 \mathrm{C}, 14 \mathrm{C}, 26 \mathrm{R}, 30 \mathrm{~K}$, and $36 \mathrm{~K}$ isolates. The amplification showed that isolates 13C, 14C, 26R, 30K, and $36 \mathrm{~K}$ generated single band sizing $1.500 \mathrm{bp}$ (base pair) following the comparator using DNA marker. This size corresponded with the expected bacterial 16S-rRNA genes with 1541 bases long. Sabdono (2001) in Sabdono et al. (2006) stated that DNA amplification of isolated singleband bacteria indicated that the primer used was a specific primer to amplify the 16S-rRNA gene in bacteria. The amplification of 16S-rRNA has become the standard for studying the phylogenetic and biodiversity of marine microorganisms (Radjasa, 2004).

After obtaining the sequence result of $13 \mathrm{C}, 14 \mathrm{C}, 26 \mathrm{R}$, $30 \mathrm{~K}$, and $36 \mathrm{~K}$ isolates, then a search on DNA database of Gen Bank using BLAST system through National Center for Biotechnology Information, National Institute for Health, USA (https://blast.ncbi.nlm.nih.gov) was carried out. The results of BLAST homology isolates 13C, 14C, $26 \mathrm{R}, 30 \mathrm{~K}$, and $36 \mathrm{~K}$ were shown in Table 1.

Results showed that bacterial isolate 13C had a sequence length of $1031 \mathrm{bp}$ and homology of $97 \%$ with bacteria Bacillus oceanisediminis strain $\mathrm{H} 2$ (Table 1). Isolate $14 \mathrm{C}$ had $1311 \mathrm{bp}$ and homology of $96 \%$ with Halomonas aquamarina strain of DSM 30161. Isolate 26R had a sequence length of 1060 bp and $98 \%$ homology with Acinetobacter pitti ATCC strain 19004. Isolate 30K had a 1097 bp and homology of 93\% with Salinicola salarius strain M27. Isolate 36K had 967 bp and showed 97\% homology with Bacillus aquimaris strain TF-12. Hagström et al. (2000) stated that isolates having a sequence of $16 \mathrm{~S}$ rRNA sequences greater than $97 \%$ may represent the same species. While the sequence equation between 93-97\% might represent bacterial identity at the genus level but different species. Bacterial isolate $26 \mathrm{R}$ had close relation with Acinetobacter pitti strain ATCC 19004 species with $98 \%$ of homology. 
Table 1. BLAST homology of isolate 13C, 14C, 26R, 30K, 36K from the database of Gen Bank DDJB.

\begin{tabular}{llll}
\hline $\begin{array}{c}\text { Sequencing } \\
\text { code }\end{array}$ & \multicolumn{1}{c}{ Name } & $\begin{array}{c}\text { Base } \\
\text { pair }(\mathbf{b p})\end{array}$ & $\begin{array}{c}\text { Homology } \\
(\boldsymbol{\%})\end{array}$ \\
\hline 13C & Bacillus oceanisediminis & 1031 & 97 \\
14C & Halomonas aquamarina & 1311 & 96 \\
26R & Acinetobacter pittii & 1060 & 98 \\
30K & Salinicola salarius & 1097 & 93 \\
$36 \mathrm{~K}$ & Bacillus aquimaris & 967 & 97 \\
\hline
\end{tabular}

The DDBJ BLAST homology results showed that isolate 26R had the same characteristics as Acinetobacter sp. with $98 \%$ homology. Acinetobacter is one of the major pathogenic bacteria that plague worldwide. Acinetobacter sp is mostly found as a bacteria causing urinary tract infections, wound infections, vascular infections, ventilator-associated pneumonia (VAP) and meningitis, especially patients with low immune systems in the intensive care unit (ICU). Research in Indonesia found that Acinetobacter as one of the most commonly infecting gram-negative bacteria that is equal to $25,8 \%$. The presence of these bacteria in the sediments is thought to be carried by the waste or surface water flow from the settlement activity.

The DDBJ BLAST homology results showed that isolate $14 \mathrm{C}$ had same characteristics as the Halomonas sp. bacteria. with a kinship rate of $96 \%$ (homology) According to Holt et al. (1994). Halomonas sp. is a gram-negative bacterium, stem cell shape, non-motile, creamy colony color, circular colony shape, flat colony elevation, coarsely colonic structure, entire colony edges, reaction to oxidase test is negative, positive towards catalase test, the ability of isolates to use glucose as a carbon source and the ability of isolates to form indole from tryptophan are negative.
Halomonas sp. produces gelatinase enzyme that can be active at $15 \% \mathrm{NaCl}$. It is possible to utilize this enzyme on an industrial scale or identify other enzymes, for example, lipase or cellulase from this isolate, with further research.

The DDBJ BLAST homology described that 13C and $36 \mathrm{~K}$ isolates had characteristics like Bacillus sp. with a kinship rate of $97 \%$ homology). Bacillus bacteria are grampositive, rod-shaped bacteria that form resistant to high temperature, low temperature, radiation, drying and disinfecting, aerobic, or anaerobic facultative (Turnbul 1996). The bacteria of the genus Bacillus have been widely used and developed as an agent to decompose organic matter and control pathogens. This potential arises from the ability of bacteria to produce various extracellular enzymes necessary for the biodegradation of organic matter as well as the ability to produce antibacterial compounds including in this case enzymes capable of liquefying certain bacteria. Therefore, this bacteria is also potential to be developed as a probiotic for bioremediation of organic matters and pathogens on shrimp farming. Bacillus's ability to produce antibacterial compounds was demonstrated by Vaseeharan and Ramasamy (2003) tested the application of Bacillus subtilis BT 23 to control vibrio bacteria in shrimp culture. In addition, the study of Banerjee et al. (2007) showed that $90 \%$ of the pathogen bacteria used as test bacteria could be inhibited by Bacillus bacteria. Balcázar and Rojas-Luna (2007) recommended the use of Bacillus subtilis UTM 126 as probiotics to control Vibrio pathogenic bacteria in vanamei shrimp culture. Also, the presence of probiotic bacteria allows the role of a growth promoter (Panigrahi and Azad 2007). Some studies show that Bacillus application affects improving shrimp growth performance such as Bacillus subtilis E20, (Liu et al. 2009), Bacillus subtilis (Far, et al. 2009).

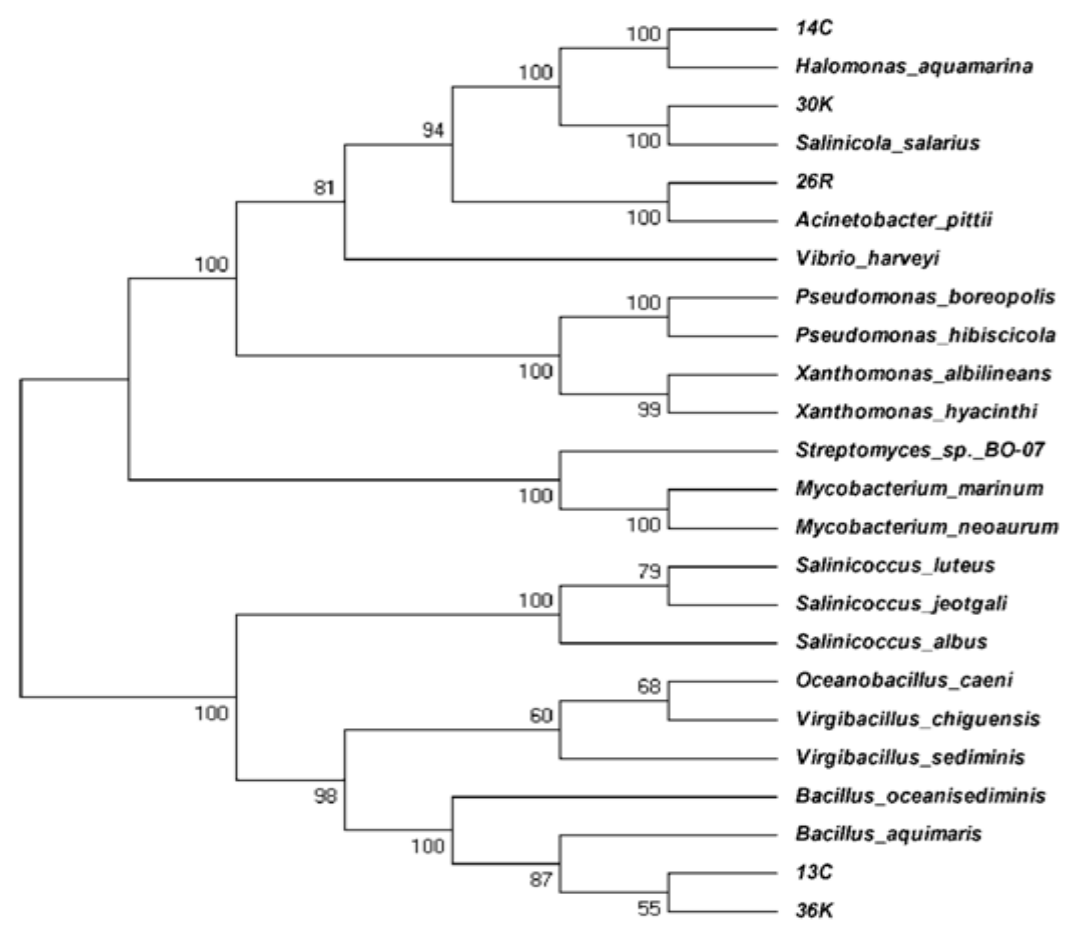

Figure 4. Phylogenetic Tree Analysis 
In conclusion, Rep-PCR on 19 isolates of proteolytic bacteria derived from the selected mangrove area obtained five clusters (groups). Group 1 consisted of five isolates of bacteria, i.e., isolates $14 \mathrm{C}, 22 \mathrm{R}, 28 \mathrm{~K}, 15 \mathrm{C}$, and $19 \mathrm{R}$ with bootstrapping values $10-77$ and $40-50 \%$ similarity value. Group 2 consisted of five bacterial, namely isolates $30 \mathrm{~K}$, $33 \mathrm{~K}, 34 \mathrm{~K}, 39 \mathrm{~K}$, and 40B with bootstrapping values 3-55 and similarity values. Group 3 consisted of 3 bacterial isolates, i.e., $13 \mathrm{C}, 2 \mathrm{C}$, and $32 \mathrm{C}$ with bootstrapping values 9-42 and similarity values ranging from 67 to $71 \%$. Group 4 consisted of five bacterial isolates, i.e., $36 \mathrm{~K}, 35 \mathrm{~K}, 37 \mathrm{~K}$, $38 \mathrm{~K}$, and 48B with bootstrapping values $8-32$ and $38-67 \%$ similarity values. Group 5 consisted of 1 isolate bacterium $26 \mathrm{R}$ with the value of bootstrapping 3 , and the value of similarity to other isolates in groups $1,2,3$, and 4 were 14 50\%. 16S-rRNA gene sequence analysis identified 13C isolates had $97 \%$ homology with Bacillus oceanisediminis strain H2. Isolate $14 \mathrm{C}$ had homology of $96 \%$ with Halomonas aquamarina strain of DSM 30161. Isolate 26R had $98 \%$ homology with Acinetobacter pitti strain ATCC 19004. Isolate 30K had $93 \%$ homology with Salinicola salarius strain M27. Isolate 36K had homology of $97 \%$ with bacteria Bacillus aquimaris strain TF-12.

\section{ACKNOWLEDGEMENTS}

The authors would like to thank Universitas Diponegoro, Semarang, Indonesia that has provided funding through funds other than APBN DPA SUKPA LPPM Universitas Diponegoro in the budget year of 2017.

\section{REFERENCES}

Annamalai N, Kumar A, Savanakumar A, Vijajlakshmi A Balasubramanian T. 2011. Characterization of protease from Algaligens faecalis and its antibacterial activity on fish pathogens. J Environ Biol 32: 781-786.

Balcázar JL, Rojas-Luna T. 2007. Inhibitory activity of probiotic Bacillus subtilis UTM 126 against Vibrio species confers protection against vibriosis in juvenile shrimp (Litopenaeus vannamei). Curr Microbiol 55: 409-12.

Banerjee S, Devaraja TN, Shariff M, Yusoff FM. 2007. Comparison of four antibiotics with indigenous marine Bacillus spp. in controlling pathogenic bacteria from shrimp and Artemia. J Fish Dis 30: 383-389.

Bernini E, Rezende CE. 2010. Litterfall in a mangrove in Southeast Brazil. Pan-Amer J Aquat Sci 5: 508-519.

Emerson D, Agulto L, Liu H, Liu L. 2008. Identifying and characterizing bacteria in an era of genomics and proteomics. BioScience 58 (10): 925.

Far HZ, Saad CRB, Daud HM, Harmin SA, Shakibazadeh S. 2009. Effect of Bacillus subtilis on the growth and survival rate of shrimp (Litopenaeus vannamei). Afr J Biotechnol 8: 3369-3376.
Gupta N, Das S, Basak UC. 2007. Useful extracellular activity of bacteria isolated from Bhitarkanika mangrove ecosystem of Orissa Coast. Malays J Microbiol 3: 15-18.

Hagström A, Pinhassi J, Zweifel UL. 2000. Biogeographical diversity among marine bacterioplankton. Aquat Microb Ecol 21: 231-244.

Hog ME, Islam MI, Paul HK, Ahmed SU. 2002. Decomposition and seasonal changes in nutrient constituent in mangrove litter of Sundarbans Mangrove, Bangladesh. Indian J Mar Sci 31: 130-135.

Holmer M, Marba N, Diaz-Almela E, Duarte CM, Tsapakis M, Danovaro R. 2007. Sedimentation of organic matter from fish farms in the oligotrophic Mediterranean assessed through bulk \& stable isotope (D13c \& D15n) analysis. Aquaculture 262: 268-280.

Holt JG, Krieg NR, Sneath PHA, Stanley JT, William ST. 1994. Bergey's Manual of Determinative Bacteriology $9^{\text {th }}$ Edition. Williams and Wilkins, Baltimore, USA.

Kristensen E, Bouillon S, Dittmar T, Machand C. 2008. Organic carbon dynamic in mangrove ecosystems: a review. Aquat Bot 89: 201-219.

Kwon KK, HS Lee, Jung SY, Yim JH, Lee JH, Lee HK. 2002. Isolation and Identification of Biofilm Farming Marine Bacteria On Glass Surface in Dee-Ko Dike, Kor J Microlide 40: 260-266.

Liu CH, Chiu CS, Ho PL, Wang SW. 2009. Improvement in the growth performance of white shrimp, Litopenaeus vannamei, by a proteaseproducing probiotic, Bacillus subtilis E20, from natto. J Appl Microbiol 107: 1031-1041.

Mahasneh AM. 2001. Bacterial decomposition of Avicennia marina leaf litter from Al-Khor (Qatar-Arabian Gulf). J Biol Sci 1: 717-719.

Marchesi JR, Sato T, Weightman AJ, Martin TA, Fry JC, Hiom SJ, Wade WD. 1998. Design and evaluation of useful bacterium-specific PCR primers that amplify genes coding for bacterial 16S-rRNA. Appl Environ Microbiol 64 (2): 795-799.

Mohan G, Thangappanpillai AKT, Ramasamy B. 2016. Antimicrobial activities of secondary metabolites and phylogenetic study of sponge endosymbiotic bacteria, Bacillus sp. at Agatti Island, Lakshadweep Archipelago. Biotechnol Rep 11: 44-52.

Panigrahi A, Azad IS. 2007. Microbial intervention for better fish health in aquaculture: the Indian scenario. Fish Physiol Biochem 33: 429440.

Qian PY, Wu MCS, Ni IH. 2001. Comparison of nutrients release among some mariculture animals. Aquaculture 200: 305-316.

Radjasa OK. 2004. Marine invertebrate-associated bacteria in coral reef ecosystems as a new source of bioactive compounds. J Coast Dev 7 (2): 65-70.

Sabdono A, Radjasa OK, Bachtiar T. 2006. Eksplorasi Senyawa Bioaktif Antifoulant Bakteri yang Berasosiasi dengan Avertebrata Laut Sebagai Alternatif Penanganan Biofouling di Laut. [Lap. Pen. HB. XII/II]. Pusat Studi Pesisir Dan Laut Tropis, Universitas Diponegoro, Semarang. [Indonesian]

Sahoo K, Dhal NK. 2008. Potential microbial diversity in mangrove ecosystems: a review. Indian J Mar Sci 38: 249-256.

Tran KTM, Maya BK, Smookera PM, Vana TTH, Coloea PJ. 2011. Distribution and genetic diversity of lactic acid bacteria from traditional fermented sausage. Food Res Intl 44: 338-344.

Turnbull PCB. 1996. Bacillus, Medical Microbiology. 4th edition. University of Texas Medical Branch at Galveston, Galveston, TX.

Vaseeharan B, Ramasamy P. 2003. Control of pathogenic Vibrio spp. by Bacillus subtilis BT23, a possible probiotic treatment for black tiger shrimp Penaeus monodon. Lett Appl Microbiol. 36 (2): 83-87.

Wullschleger S, Lacroix C, Bonfoh B, Sissoko-Thiam A, Hugenschmidt S, Romanens E, Baumgartner S, Traoré I, Yaffee M, Jans C, Meile L. 2013. Analysis of lactic acid bacteria communities and their seasonal variations in a spontaneously fermented dairy product (Malian fènè) by applying a cultivation/genotype-based binary model. Intl Dairy $\mathbf{J}$ 29: 28-35. 